M.P. Menezes https://orcid.org/0000-0002-0294-5126 R.C. Costa https://orcid.org/0000-0001-6404-2603 M.E.B.A.M. Conceição https://orcid.org/0000-0002-6939-2183

B.W. Minto

\section{Treatment of a femoral septic nonunion in a dog with interlocking nail stabilization associated to corticospongious bone autograft and greater omentum flap: case report}

\author{
[Tratamento de não união séptica femoral em cão com estabilização com haste \\ intramedular bloqueada associada a autoenxerto de osso corticoesponjoso \\ e retalho do omento maior: relato de caso] \\ M.P. Menezes, R.C. Costa, M.E.B.A.M. Conceição, \\ B.W. Minto, L.G.G.G. Dias*
}

Universidade Estadual Paulista "Júlio de Mesquita Filho" - Jaboticabal, SP https://orcid.org/0000-0002-8808-4127 L.G.G.G. Dias https://orcid.org/0000-0003-3993-1649

\begin{abstract}
Chronic septic bone nonunion requires a well-designed therapeutic planning, demanding a multimodal treatment to achieve bone consolidation and elimination of infection. A successful case of an association of the major omentum flap with surgical stabilization with an interlocking nail for treatment of a femoral septic nonunion in dog is reported. The patient had partial functional return of the limb 30 days after surgery, negative bacterial culture with radiographic signs of bone healing and total functional return of the limb at $90^{\text {th }}$ days after the surgical procedure.
\end{abstract}

Keywords: complication, orthopaedics, osteomyelitis, planning

\title{
RESUMO
}

Não uniões ósseas associadas à osteomielite crônica necessitam de um planejamento terapêtico muito bem realizado, demandando tratamento multimodal para conseguir atingir a consolidação óssea e eliminar a infecção. Relatou-se um caso de sucesso do uso da associação de retalho do omento maior com estabilização cirúrgica com haste intramedular bloqueada para tratamento de uma não união séptica de fêmur em cão. O paciente apresentou retorno funcional parcial do membro com 30 dias após a cirurgia, cultura bacteriana estéril com sinais radiográficos de consolidação óssea e retorno funcional total do membro aos 90 dias de pós-operatório.

Palavras-chave: complicação, ortopedia, osteomielite, planejamento

\section{INTRODUCTION}

Chronic osteomyelitis culminates in intermittent or persistent lameness, cutaneous fistulas, local pain and swelling, hyperesthesia, pyrexia and anorexia in addition to extensive bone resorption with consequent replacement by fibrous tissue and bone sequestration impairing osteogenic activity and contributing to biologically inactive nonunion development due to the small local vascularization (Sturion et al., 2000).

Recebido em 23 de novembro de 2018

Aceito em 12 de julho de 2019

*Autor para correspondência (corresponding author)

E-mail: gustavogosuen@gmail.com
The treatment of septic bone nonunion is long, difficult and expensive, requiring aggressive surgical lavage, medullar canal reopening, rigid stabilization and use of osteogenic promoters associated with systemic and local antibiotic therapy, adequate drainage establishment and dead space management (Bubenik and Smith, 2003).

Omentum can preserve its immunogenic and angiogenic capacity as well as its potential of drainage even in distant places when used as flap through the subcutaneous, being able to 
potentiate several surgical procedures (Ito et al., 2010). The use of the omentum properties for treatment on biologically inactive nonunion associated with chronic osteomyelitis as reported by McAlinden et al. (2009), are not common in the consulted literature, so the present report aimed to describe step by step the success of its use in the treatment of a young dog femoral septic nonunion case.

\section{CASE REPORT}

A male 9 month-old Blue Heeler, weighing 13 kilograms with a nonunion of the right femur and assumed chronic osteomyelitis was admitted six weeks after being hit by a car and previously received intramedullary pin implantation, in combination with Thomas's crutch stabilization. In the clinical examination, the vital parameters assessed were: heart rate $=100$ beats per minute, respiratory rate $=60$ movements per minute, capillary refill time $=1$ second, normal oral mucous membrane and rectal temperature $=39^{\circ} \mathrm{C}$. The patient exhibited deviation of the right hindlimb's axis, functional impotence of the limb, presence of fibrous callus, painful palpation and presence of fistulas at the medial and caudal limb's proximal extremity (Figure 1A and 1B). Radiographic exams showed a complete comminuted fracture in the middle third of the right femur, irregular and sharp fragment edges and edema of the adjacent soft tissue (Figure 2A and 2B). The patient was diagnosed with a femoral septic nonunion.

After proper position (left lateral decubitus) and rigorous antisepsis with chlorhexidine digluconate $2 \%$ and alcohol $70 \%$, the femoral diaphysis was surgically accessed and large amounts of fibrous tissue, purulent secretion, and multiple devitalized bone fragments were removed (Figure 1C). The edges of each bone fragment were abraded using a gouge tool, resulting in significant bone lack at the fracture site (Figure 1D). The adjacent tissue was swabbed, and bone fragments were collected for bacterial culture and antimicrobial susceptibility testing. The surgery site was washed with sterile saline solution.
A 100 millimeters (mm) long, 6mm thick interlocking nail (Interlocking nail, Protomed, Brazil) was inserted into the trochanteric fossa, with two proximal and two distal locking holes, which accommodated the locking screws (locking screws, Cãomédica, Brazil), stabilizing the system (Figure 3A and 3B).

After change of clothing, material, and surgical field, laparotomy was performed through the right flank, caudal to the 13th rib, to generate a flap of the greater omentum, which was guided to the fracture site through a subcutaneous tunnel (Figure 1E). Corticospongious bone autograft was isolated from the right iliac crest and deposited on the fracture site (Figure 1F). Femoral diaphysis was covered by the greater omentum flap (Figure 1G), and tissues were closed with nonabsorbable monofilament sutures.

Due to bone loss and muscle contraction, there was an approximate $25 \%$ decrease in the length of the operated limb, compared to the contralateral limb. The patient was kept on sodium cefazolin and metronidazole also analgesic and gastric protector therapy, and wound cleaning with $\mathrm{NaCl} 0,9 \%$. After two days, the results of the bacterial culture and antimicrobial susceptibility testing revealed the presence of Klebsiella sp., sensitive to the quinolones, and the antimicrobial therapy was changed, accordingly, to enrofloxacin.

The patient presented partial limb support and fistulas and surgical incision sealed at 15 postoperative days and adequate limb support performing hyperextension of the knee and tarsal joint at 30 days (Figure 1H). Radiographic images revealed no signs of osteomyelitis and beginning of the formation of bone bridges at the fracture site (Figure 3C and 3D).

At 90 days after surgery, the patient had normal limb function and no signs of infection. The radiographs showed signs of bone consolidation, although it showed fragility of the bone column at the fracture site. An addition, minimally invasive surgical intervention was performed in order to dynamize the implant by the removal of the second and third screws (Figure $3 \mathrm{E}$ and $3 \mathrm{~F}$ ). 


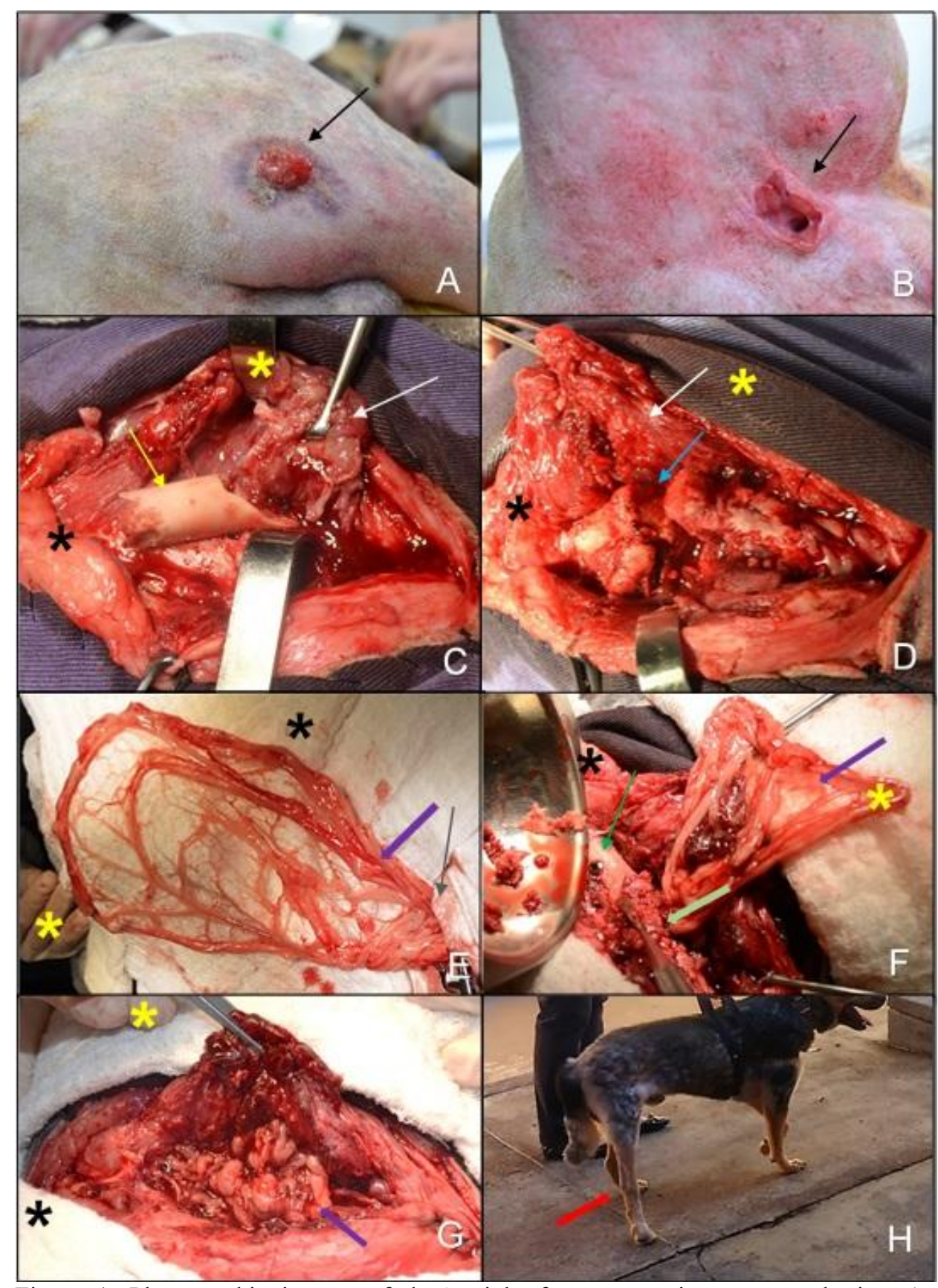

Figure 1. Photographic images of dog's right femur nonunion osteosynthesis. The yellow asterisk illustrates the cranial direction of the limb and the black asterisks indicate the proximal direction. (A) Fistula (black arrow) in the caudo-lateral aspect of the right limb; (B) fistulous path in the medial face of the right limb; (C) evidence of devitalized bone fragments (yellow arrow) and large amount of fibrous tissue (white arrow); (D) Bone defect (blue arrow) after surgical debridement; (E) the greater omentum (purple arrow), collected after caudal laparotomy, at the 13th right rib, passed through the subcutaneous space (grey arrow) to the fracture site; (F) Placement of the Corticospongious bone autograft at the fracture site (light green arrow). Green arrow indicates the locking screw used on the interlocking nail; (G) femoral diaphysis overlapped with the omentum flap. (H) The patient, after thirty days, exhibiting adaptive support by hyperextension of the tibiotarsal joint (red arrow) and stifle joint. 


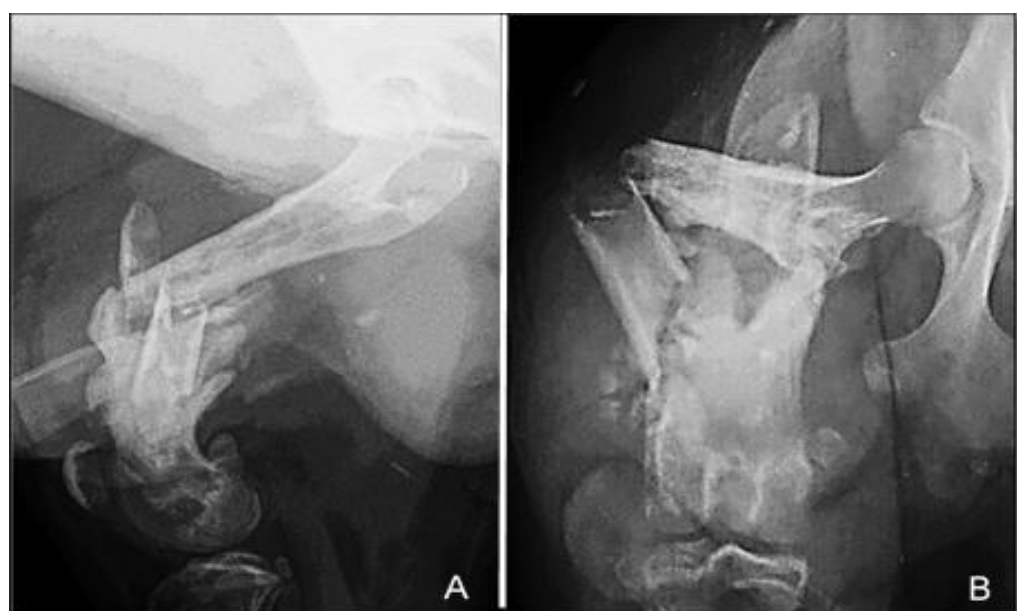

Figure 2. Preoperative radiographic images in the (A) mediolateral and (B) craniocaudal projections, illustrating a complete comminuted fracture of the middle third of a canine right femur, with irregular and sharp fragment edges, and edema of the adjacent soft tissue. The radiographic signs are compatible with a septic nonunion.

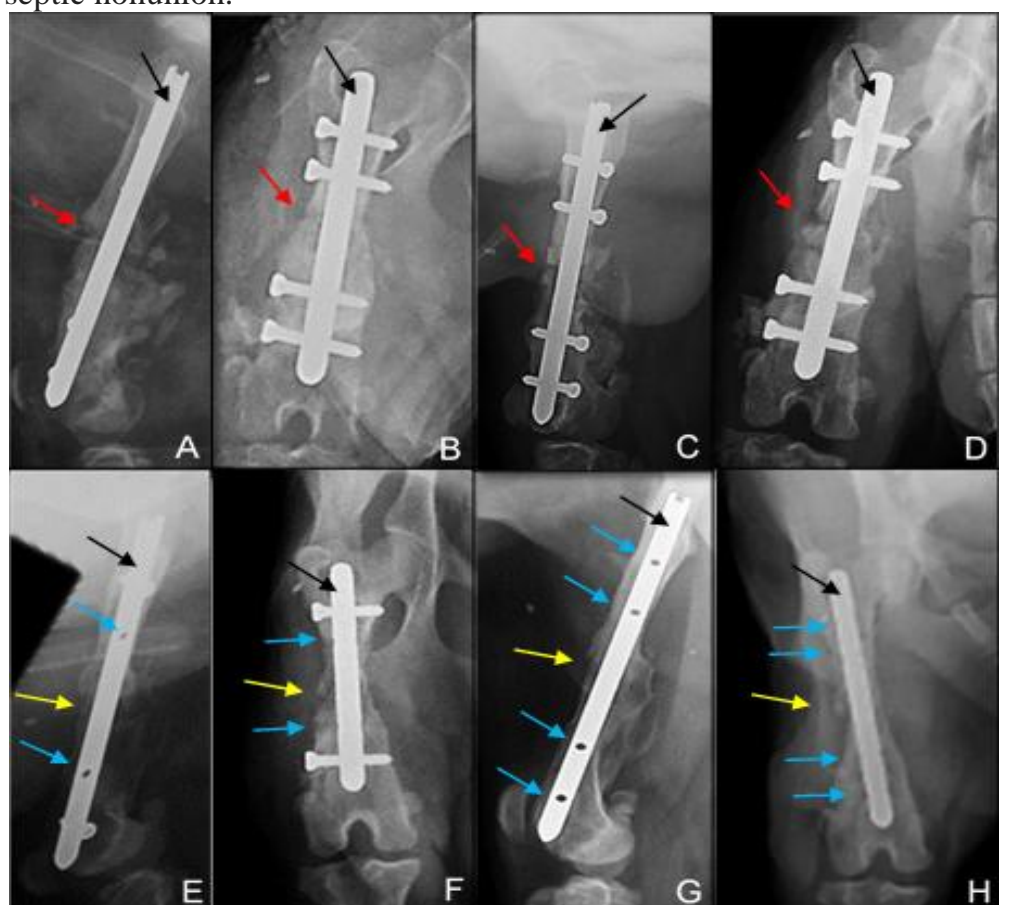

Figure 3. (A, B) Postoperative radiographic images of canine right femur, immediately after osteosynthesis as treatment of a bone septic nonunion, in medio-lateral (A) and cranio-caudal (B) projections, focusing on the implant used, an interlocking nail (black arrow) with 4 locking screws and on the presence of a radiolucent line indicating the fracture site (red arrow). (C, D) Radiographic images of the same patient, at 30 days after surgery, showing the onset of bone consolidation, in the medio-lateral (C), and cranio-caudal (D) projections. (E, F) Radiographic images in the medio-lateral (E) and craniocaudal (F) projections, at 100 days after osteosynthesis, note the implant dynamization by the removal of the locking screws, closer to the focus of the fracture (blue arrows), showing bone consolidation (yellow arrows). (G, H) Radiographic images at 170 days after the first surgery, immediately after the second dynamization, in which the two remaining screws were removed, in medio-lateral $(\mathrm{G})$ and cranio-caudal $(\mathrm{H})$ projections. 
Antimicrobial therapy was discontinued three days before the surgical re-intervention, and a new bacterial culture and antimicrobial susceptibility testing performed on the removed implants confirmed the absence of infectious agents. Radiographic evaluation showed an improvement in bone quality, and reinforcement of the bone column at eighty days after dynamization. A new minimal intervention to remove the remaining screws was done (Figure $3 \mathrm{G}$ and $3 \mathrm{H}$ ). These screws also presented absence of microorganisms. Upon full recovery of hindlimb function, absence of pain, no signs of infection, and total femur consolidation at 270 days after surgery, the patient was discharged.

\section{DISCUSSION}

Comminuted fractures of femur diaphysis could be treated with interlocking nails, because these implants offer a larger and more uniform area moment of inertia, allowing effective resistance to bending force in all planes and they are indicated in biologic osteosynthesis (Guiot and Déjardin, 2017). Additionally, the interlocking nails promote a rigid fixation ensuring anatomic alignment and mechanical function, important features in implant decision making in nonunion cases (Kraus and Bayer, 2017). The treatment of chronic osteomyelitis includes intense local debridement, removal of potentially infected and devitalized bone, muscle and fibrous tissue, culturing of collected material and antibiogram testing, sterile local lavage, and fracture stabilization (Sturion et al., 2000).

Nonunion can occur due to instability of the fracture site and infection with simultaneous presence of bone sequestrum (Pneumaticos et al., 2014), which was confirmed in the present case. We admitted the patient presenting a not stabled chronic fracture, which had sings of infection, as fistulae and purulent secretion. The diagnosis of a septic nonunion had been confirmed by clinical signs and positive bacterial cultures as indicated by some autors (Sturion et al., 2000).

Klebsiella sp., an enterobacterium, isolation, could indicate fecal contamination, inadequate cleaning and disinfection of the environment, in a study on this subject at a veterinary hospital, the author affirmed that this kind of infection is an emerging problem because of its potential to lead to multiple antibiotic-resistant bacterial strains (Suthar et al., 2014).

Despite the recommendations for stabilization with external fixation in cases of bacterial infection, in the present case, this method was not chosen due to the possibility of implant failure before the achievement of bone consolidation (Bubenik and Smith, 2003). The choice of the interlocking nail was based on its biomechanical superiority, longer period of patency and its potential for dynamization (Déjardin et al., 2012). Similar to our case, a study in radial nonunion in small breed dogs, which used reconstruction plates with allogenous bone graft, showed that the use of internal fixation in infected nonunion had no difference in consolidation period than that which were not infected and showed no signs of infection after discontinuation of the antibiotic medication (Munakata et al., 2018).

The use of the greater omentum flap at the fracture site may have contributed to the increased reach and action of the antimicrobial agents for the treatment of the infection, and also to the improved circulation of neutrophils, macrophages, fibroblasts, and endothelial cells also allowing and supporting the drainage and filling of the empty space, Baltzer et al. (2015), in a retrospective analyzes, compared two groups of radius fracture in small breed dogs, on one of the groups they used only internal fixation, and on the other one, used internal fixation with greater omentum flap, they observed a shorter consolidation time in the second and shorter median time to healing, concluding that the vascularization of the greater omentum did not suffer any apparent damage, after its passage through the subcutaneous space, guaranteeing its full performance at the fracture site (Ito et al., 2010)

Some complications cited by literature, using omentum in another site outside of the abdomen are erythema and subcutaneous edema (Baltzer $e t$ al. 2015), which were not found in the present case, maybe it happened as a hyper sensibility reaction in some patients and our patient did not show that.

The present case management followed the evidence-based protocols for antimicrobial therapy, including the use of broad-spectrum, 
perioperative, antibiotics and concurrent culture and antibiogram assays to identify the best antibiotic and period of application in the post operatory, followed by occasional repetition of the culturing assays (Haidar et al., 2010).

Despite the radiographic signs of bone healing, the narrowing of the bone column at the point of fracture site supported the decision for the first implant dynamization to increase the load bearing by the bone tissue, and stimulate the osteogenic activity, as evaluated in others' work, with positive results (Lynch et al., 2008).

As reported by other authors who used the omentum as an adjuvant in the treatment of fractures (McAlinden et al., 2009), in this case, the bone healing occurred, surprisingly, within 12 weeks. The omentum probably contributed to the reduction of the recovery time, mainly due to the support it provided to the control of osteomyelitis. Additionally, the omentum may have contributed to the biological recovery of the fracture site by the induction of neovascularization (Baltzer et al., 2015).

\section{CONCLUSION}

The treatment strategy chosen for the femoral septic nonunion proved to be effective, providing biological recovery of the fracture and consequent bone consolidation with functional recovery of the limb. Moreover, it allowed infection control by the utilization of evidencebased antibiotic therapy, highlighting the importance of repetitive bacterial cultures and antimicrobial susceptibility testing. This case also highlights the importance of the dynamization of the implants for increased load bearing by the bone and it showed that the omentum flap in the fracture site did not present complications that would discourage its use.

\section{REFERENCES}

BALTZER, W.I.; COOLEY, S.; WARNOCK, J.J. et al. Augmentation of diaphyseal fractures of the radius and ulna in toy breed dogs using a free autogenous omental graft and bone plating. Vet. Comp. Orthop. Traumatol., v.28, p.131-139, 2015
BUBENIK, L. J.; SMITH, M. M. Orthopaedic infections. In: SLATTER, D. (Ed.). Textbook of small animal surgery. 3.ed. Philadelphia: Saunders, 2003. 2896p.

DÉJARDIN, L.M.; GUIOT, L.P.; VON PFEIL, D.J.F. Interlocking nails and minimally invasive osteosynthesis. Vet. Clin. Small Anim., v.42, p.935962, 2012

GUIOT, L.P.; DEJARDIN, L.M. Fractures of the femur. In: JOHNSTON, S.A.; TOBIAS, K.M. (Eds). Veterinary Surgery. 2 ed., St Louis: Sauders Elsevier, 2017, p.2817-2924.

HAIDAR, R.; BOGHOSSIAN, A.D.; ATIYEH, B. Duration of post-surgical antibiotcs in chronic osteomyelitis: empiric or evidence-based? Int. J. Infect. Dis., v.14, p.752-758, 2010.

ITO, K.; FERRIGNO, C.R.A.; ALVES, F.R. Extensão máxima de retalho pediculado de omento maior através de túnel subcutâneo para ossos longos em cães. Ciênc. Rural, v.40, p.594-599, 2010.

KRAUS, K.H.; BAYER, B.J. Delayes unions, nonunions, and malunions. In: JOHNSTON, S. A.; TOBIAS, K.M. (Eds). Veterinary Surgery. 2 ed., St Louis: Sauders Elsevier, 2017, p.2128-2151.

LYNCH, J.R.; TAITSMAN, L.A.; BAREI, S.P.; NORK, S.E. Femoral nonunion: risk factors and treatment options. J. Am. Acad. Orthop. Surg., v.16, p.88-97, 2008.

McALINDEN, A.; GLYDE, M.; MCALLISTER, H.; KIRBY, B. Omentalisation as adjunctive treatment of an infected femoral nonunion fracture: a case report. Ir. Vet. J., v.62, p.663-668, 2009.

MUNAKATA, S.; NAGAHIRO, Y.; KATORI, D. et al. Clinical efficacy of bone reconstruction surgery with frozen cortical bone allografts for nonunion of radial and ulnar fractures in toy breed dogs. Vet. Comp. Orthop. Traumatol., v.31, p.159-169, 2018.

PNEUMATICOS, S.G.; PANTELI, M.; TRIANTAFYLLOPOULOS, G.K. et al. Management and outcome of diaphyseal aseptic non-unions of the lower limb: a systematic review. Surgeon, v.12, p.166175, 2014.

STURION, D.J.; ISQUERDO, R.; LAGANARO, S.L. et al. Aspects clinics and treatment of osteomyelites. Unopar Cient. Ciênc. Biol. Saúde, v.2, p.151-160, 2000.

SUTHAR, N.; ROY, S.; CALL, D.R. et al. An individual based model of transmission of resistant bactéria in a veterinary teaching hospital. Plos One., v.9, p.1-10, 2014. 